\title{
Gene expression of vasoactive intestinal contractor/endothelin-2 in ovary, uterus and embryo: comprehensive gene expression profiles of the endothelin ligand-receptor system revealed by semi-quantitative reverse transcription-polymerase chain reaction analysis in adult mouse tissues and during late embryonic development
}

\section{Tsuyoshi Uchide, Hiromi Masuda, Youji Mitsui and Kaname Saida}

National Institute of Bioscience and Human-Technology, Agency of Industrial Science and Technology, Tsukuba, Ibaraki 305-8566, Japan

(Requests for offprints should be addressed to K Saida, National Institute of Bioscience and Human-Technology, Agency of Industrial Science and Technology, 1-1 Higashi, Tsukuba, Ibaraki 305-8566, Japan)

\begin{abstract}
Vasoactive intestinal contractor (VIC)/endothelin-2 (ET-2) is a 21 amino acid intestinal peptide characterized as a potent vasoactive and intestinal smooth muscle-contracting compound. To investigate the physiological roles of VIC/ET-2 further, we characterized the specificity of VIC gene expression relative to that of other members of the endothelin (ET) ligand-receptor system in adult mouse tissues and during embryonic development. Gene expression of ET-1, ET-3, ETA and ETB was ubiquitous in almost all tissues we examined while gene expression of VIC was localized to certain tissues. A high level of VIC gene expression was observed in ovary and uterus. The gene
\end{abstract}

expression of VIC, relative to that of glyceraldehyde-3-phosphate dehydrogenase, was approximately $2 \cdot 0 \%, 0 \cdot 4 \%$, and $2 \cdot 3 \%$ in ovary, uterus, and intestine respectively, and was approximately $1 \cdot 6$ and $7 \cdot 1$ times higher than that of ET- 1 in ovary and intestine respectively. Thus, VIC may have some physiological role in adult ovary and uterus as well as intestine. In embryonic development, VIC gene expression sharply increased between 11 and 15 days post coitus and decreased after birth, suggesting an involvement in the later stages of embryonic development.

Fournal of Molecular Endocrinology (1999) 22, 161-171

\section{INTRODUCTION}

The endothelin (ET) system, composed of three ligands and two receptors, plays an important physiological role in mammals. ET family ligands, which include endothelin-1 (ET-1), vasoactive intestinal contractor (VIC)/endothelin-2 (ET-2), and endothelin-3 (ET-3), are peptides composed of 21 amino acid residues. These isopeptides have a variety of biological roles, including involvement in vasoconstriction (Yanagisawa et al. 1988), bronchial smooth muscle contraction (Mckay et al. 1991), and cell growth (Lahav et al. 1996, Mazzocchi et al. 1997). The effects of these peptides are mediated by receptors (ETRs) that are classified into two subtypes, the endothelin A receptor (ETA) and the endothelin B receptor (ETB). Previous studies demonstrated that the expression of ET-1 or ET-3 and ETA or ETB mRNAs are co-localized in various tissues, suggesting that ET-1 and ET-3 function in an autocrine or paracrine manner (MacCumber et al. 1989, Huggins et al. 1993). ET-1 and ET-3 appear to play an important role in embryonic development. Targeted gene inactivation 
experiments showed the ET-1/ETA pathway was essential for the development of tissues derived from cephalic and cardiac neural crest cells (Kurihara et al. 1994, 1995, Clouthier et al. 1998). ET-3 and ETB knockout mice exhibit spotted coat color and megacolon resulting from the absence of epidermal melanocyte and enteric neurons, showing the importance of the ET-3/ETB pathway in the development of tissues derived from vagal and trunk neural crest cells (Baynash et al. 1994, Hosoda et al. 1994).

VIC is a mouse intestinal peptide characterized as a potent vasoactive and intestine-contracting compound (Ishida et al. 1989, Saida et al. 1989, Blank et al. 1991, Wollberg et al. 1991, Yoshinaga et al. 1992, Taniyama et al. 1993, Fang et al. 1994, Kan et al. 1994, de la Monte et al. 1995). ET-2 is a human-derived peptide characterized as a potent vasoconstrictor (Inoue et al. 1989). VIC differs from ET-2 in 1 amino acid of 21 residues and may be the mouse or rat counterpart of human ET-2 (Bloch et al. 1991). Throughout this manuscript we use the symbol VIC/ET-2 to represent either of these peptides. Structurally, VIC/ET-2 is highly homologous to ET-1. VIC differs from ET-1 in 3 amino acids of 21 residues, ET-2 differs from ET-1 in 2 amino acids. There are no obvious differences in antigenicity between VIC/ET-2 and ET-1, nor are there any differences in their selectivity for ETA or ETB receptors. These similarities make it difficult to analyze the specific biological activities for each ligand. Although the biological activities and physiological roles of ET-1 and ET-3 have been well documented thus far, little is known about the specific physiological role of VIC/ET-2. The tissue distribution of VIC/ET-2 mRNA, determined by RNase protection assay, in rat gastrointestinal tract has been reported (de la Monte et al. 1995). However few reports on the comprehensive tissue distribution of VIC/ET-2 mRNA in various adult tissues and throughout embryogenic development are available. Moreover, to our knowledge no comprehensive quantitative and comparative study of the gene expression of all members of the ET system has yet been reported. Thus, it is important to identify the specific tissues and developmental stages in which the VIC/ET-2 gene is preferentially expressed and to characterize the quantity of the VIC/ET-2 gene expression in comparison with other genes of the ET system, in an attempt to understand the specific physiological roles of VIC/ET-2 in vivo.

We established a semi-quantitative reverse transcription-linked polymerase chain reaction (RT-PCR) to analyze the gene expression levels of all the ligands and receptors of the ET system. We then examined the expression levels of each gene quantitatively in tissues of adult mice and in embryos in the later stages of development using the RT-PCR method to characterize the specificity of VIC gene expression.

\section{MATERIALS AND METHODS}

\section{Mice}

Adult 9-week-old male as well as pregnant and non-pregnant adult 9-week-old female Slc:ICR mice were obtained from Japan Clea (Tokyo, Japan). Embryos at 11, 15, and 17 days post coitus (E11, E15, and E17) and neonates 1 day post partum (P1) were obtained from the pregnant mice. Our experimental procedures were in accordance with the Guidelines on Handling and Care of Laboratory Animals by the Universities Federation for Animal Welfare in the UK.

\section{mRNA preparation}

Immediately on induction of anesthesia the following tissues were removed: brain (cerebrum and cerebellum), heart, lung, stomach, intestine, liver, kidney, spleen, uterus, ovary, and testis. The excised tissues, whole embryos and neonates were washed well with phosphate-buffered saline (PBS(-)) on ice and weighed. One hundred milligrams of each tissue were immediately homogenized. Total RNAs were prepared from the homogenate using Isogen solution (Nippon Gene, Tokyo, Japan) according to the manufacturer's protocol. Poly $(\mathrm{A})^{+}$RNAs were obtained from the total RNAs by oligo(dT)-cellulose chromatography (Pharmacia, Uppsala, Sweden).

\section{Cloning of cDNAs used as control templates}

cDNAs of the three ligands (ET-1, VIC/ET-2, and ET-3) and two receptors (ETA and ETB) have been cloned previously in our laboratory by screening a cDNA library (Saida \& Mitsui 1991, Kurama et al. 1996, and T Uchide \& K Saida, unpublished data). The restriction fragments and PCR products were cloned using a pCR-Script SK+ Cloning Kit (Stratagene, La Jolla, CA, USA) according to the manufacturer's protocol, and were sequenced using a DyeDeoxy Terminator Cycle Sequencing Kit and Model 373A DNA Sequencer (PE Applied Biosystems, Foster City, CA, USA). The cDNAs inserted in plasmids were used as quantitative controls to estimate the expression level of each gene. 
TABLE 1. PCR conditions optimized for semi-quantitative cDNA amplification for the ET system and GAPDH

\begin{tabular}{|c|c|c|c|}
\hline & Primers (sense/antisense, $5^{\prime} \rightarrow 3^{\prime}$ ) & $\begin{array}{l}\text { No. of } \\
\text { cycles }\end{array}$ & $\begin{array}{l}\text { Product } \\
\text { size (bp) }\end{array}$ \\
\hline \multicolumn{4}{|l|}{ cDNA } \\
\hline \multirow[t]{2}{*}{ VIC } & CTGCTGCTGTGTTAAAGACTGGCAAG & 35 & 652 \\
\hline & AGGTTCTGTGCTCCCAAAAGTGTCC & & \\
\hline \multirow[t]{2}{*}{ ET-1 } & AGCTGGTGGAAGGAAGGAAACTACG & 35 & 728 \\
\hline & GACAGTGCAGAAAGGTGAGGTAGACT & & \\
\hline \multirow[t]{2}{*}{ ET-3 } & CTTGTATGGGGGCGGATGACAAG & 35 & 679 \\
\hline & TGCCTCGCTAACTTGCTCAGGC & & \\
\hline \multirow[t]{2}{*}{ ETA } & CCCTTGATTACCGCCATTGAAA & 35 & 346 \\
\hline & TGACAACCAAGCAGAAGACAGT & & \\
\hline \multirow[t]{2}{*}{ ETB } & GGCTAGTGTGTTTTCAGAGGCTTG & 35 & 822 \\
\hline & CAGAACCACAGAGACCACCCAAAT & & \\
\hline \multirow[t]{2}{*}{ GAPDH } & TTCATTGACCTCAACTACATG & 25 & 443 \\
\hline & GTGGCAGTGATGGCATGGAC & & \\
\hline
\end{tabular}

Annealing temperature at $60^{\circ} \mathrm{C}$, AmpliTaq Gold DNA polymerase and template concentration at $5 \mathrm{ng}$ single stranded $\mathrm{cDNA} / 20 \mu \mathrm{l}$.

\section{Design of primers and RT-PCR reaction}

Oligonucleotide primer pairs specific for mouse genes of VIC, ET-1, ET-3, ETA, ETB, and glyceraldehyde-3-phosphate dehydrogenase (GAPDH) were designed to amplify each specific band without producing any accessory bands. Optimized primer sequences and the predicted amplification products are listed in Table 1. The primers span an intron-exon boundary, so that each amplification product could be taken as a representative of tissue mRNA expression and not a contamination of genomic DNA.

cDNAs were generated using $\operatorname{Poly}(\mathrm{A})^{+}$RNAs as templates in the reverse transcriptase (RT) reaction mixture, which contained $2.5 \mu \mathrm{M}$ random primer, 1 unit/ $\mu$ l RNase inhibitor, $1 \mathrm{mM}$ dNTP, $5 \mathrm{mM}$ $\mathrm{MgCl}_{2}, 0.25$ unit/ $\mu \mathrm{l} \mathrm{RT}$, and $\mathrm{RT}$ reaction buffer $(10 \mathrm{mM}$ Tris- $\mathrm{HCl} \mathrm{pH} \quad 8 \cdot 3, \quad 50 \mathrm{mM} \mathrm{KCl})$, by incubating at $30{ }^{\circ} \mathrm{C}$ for $10 \mathrm{~min}$ and then at $42{ }^{\circ} \mathrm{C}$ for $30 \mathrm{~min}$ in a Thermal Cycler Model MP (Takara, Tokyo, Japan). After the incubation the reaction mixture was heated to $99^{\circ} \mathrm{C}$ for $5 \mathrm{~min}$. The RT product was amplified in a $\mathrm{PCR}$ reaction mixture $(20 \mu \mathrm{l})$ containing $2.5 \mathrm{mM} \mathrm{MgCl}_{2}, 200 \mu \mathrm{M}$ dNTP, $0.5 \mu \mathrm{M}$ each of antisense and sense primers, 0.25 units of Ampli Taq Gold DNA polymerase (PE Applied Biosystems) and PCR buffer $(10 \mathrm{mM}$ Tris- $\mathrm{HCl} \mathrm{pH} \mathrm{8 \cdot 3,50} \mathrm{mM} \mathrm{KCl}$ ). After preheating at $95{ }^{\circ} \mathrm{C}$ for $9 \mathrm{~min}$, we performed the following sequential steps for 25 (GAPDH) or 35 cycles (ETs and ETRs): $95^{\circ} \mathrm{C}$ for $1 \mathrm{~min}, 60^{\circ} \mathrm{C}$ for $1 \mathrm{~min}$, and $72{ }^{\circ} \mathrm{C}$ for $2 \mathrm{~min}$. The final incubation was performed at $72{ }^{\circ} \mathrm{C}$ for $10 \mathrm{~min}$. PCR products were run in $2 \%$ agarose gels, stained with ethidium bromide, and then photographed under UV illumination.

\section{Semi-quantitative RT-PCR analysis; optimized PCR conditions}

We employed a semi-quantitative RT-PCR method based on a previously described method (Ozawa et al. 1996, 1997) for analysis of gene expression of the ET system. The optimum number of amplification cycles and dilution levels of reversetranscribed cDNA tissue samples used for semiquantitative PCR were chosen within the linear range of the reaction (Table 1). We used AmpliTaq Gold (PE Applied Biosystems) polymerase to avoid producing accessory bands and to support sufficient amplification in later cycles, which were difficult in Taq polymerase. We optimized specific primers for eliminating the production of accessory bands. The optimized PCR conditions (Table 1) enabled us to estimate the starting template molecules over two to three orders of magnitude in the visible range of the ethidium bromide staining in agarose gel electrophoresis (Figs 1 and 2C), confirming that quantification of products was done during the linear phase of amplification.

\section{Standard curves}

We amplified various amounts of pre-determined standard cDNA templates simultaneously with tissue sample templates in separate tubes, and estimated the expression level of a particular gene by comparing the band intensity of sample templates with that of standard templates (Figs 1, $2 \mathrm{C}$ and $4 \mathrm{~A})$. Each standard template cDNA of the ET system (VIC, ET-1, ET-3, ETA and ETB) and GAPDH was serially $\left(10^{-\mathrm{n}}\right.$ or $\left.3 \times 10^{-\mathrm{n}}\right)$ diluted (lanes $1-8$ in Fig. 1). The starting numbers of 
serially diluted standard cDNA template molecules per each PCR reaction $(20 \mu \mathrm{l})$ were: $2 \cdot 4 \times 10$ (lane 1), $7 \cdot 2 \times 10$ (lane 2$), 2 \cdot 4 \times 10^{2}$ (lane 3$), 7 \cdot 2 \times 10^{2}$ (lane 4), $2.4 \times 10^{3}$ (lane 5), $2.4 \times 10^{4}$ (lane 6), $2 \cdot 4 \times 10^{5}$ (lane 7 ), $2 \cdot 4 \times 10^{6}$ molecules (lane 8) for ET-1; $2.5 \times 10$ (lane 1$), 7 \cdot 5 \times 10$ (lane 2$), 2.5 \times 10^{2}$ (lane 3), $7.5 \times 10^{2}$ (lane 4), $2.5 \times 10^{3}$ (lane 5), $2.5 \times 10^{4}$ (lane 6), $2.5 \times 10^{5}$ (lane 7$), 2.5 \times 10^{6}$ molecules (lane 8) for VIC and ET-3; $2.8 \times 10$ (lane 1), $8.4 \times 10($ lane 2$), 2.8 \times 10^{2}$ (lane 3$), 8.4 \times 10^{2}$ (lane 4), $2.8 \times 10^{3}$ (lane 5), $2.8 \times 10^{4}$ (lane 6), $2 \cdot 8 \times 10^{5}$ (lane 7$), 2 \cdot 8 \times 10^{6}$ molecules (lane 8$)$ for ETA; $2.0 \times 10$ (lane 1), $6.0 \times 10$ (lane 2), $2 \cdot 0 \times 10^{2}$ (lane 3), $6.0 \times 10^{2}$ (lane 4), $2.0 \times 10^{3}$ (lane 5), $2.0 \times 10^{4} \quad$ (lane 6), $2.0 \times 10^{5} \quad$ (lane 7$), 2.0 \times 10^{6}$ molecules (lane 8) for ETB; $2.7 \times 10^{3}$ (lane 1), $8 \cdot 1 \times 10^{3}$ (lane 2), $2.7 \times 10^{4}$ (lane 3 ), $8.1 \times 10^{4}$ (lane 4), $2.7 \times 10^{5}$ (lane 5), $2.7 \times 10^{6}$ (lane 6), $2.7 \times 10^{7}$ (lane 7), $2.7 \times 10^{8}$ molecules (lane 8) for GAPDH. The starting number of molecules was calculated from the molecular weights $(\mathrm{g} / \mathrm{mole})$ of each PCR product (bp) and amounts (pg) of each serially diluted control cDNA. The intensities of the bands were analyzed by computer.

\section{Specificity analysis of $P C R$ products: Southern hybridization and restriction enzyme digestion}

The specificity of each band was determined by Southern hybridization and restriction enzyme digestion to produce bands corresponding to expected fragment lengths. PCR products separated in agarose gels were transferred onto nylon membranes (Boehringer Mannheim, Mannheim, Germany). The membranes were hybridized with each specific probe; cloned cDNA was labeled with digoxygenin-dUTP by random priming method (DIG DNA Labeling kit, Boehringer Mannheim). The protocols of hybridization, washing and chemiluminescence detection were as previously described (Engler-Blum et al. 1993). Each PCR product was digested with a restriction enzyme appropriate for producing fragments of expected lengths for identifying the specificity of PCR products.

\section{Gene expression rate}

Using the relative intensity of bands (Fig. 1) and the linear range of the standard curve (as shown in Fig. $2 \mathrm{C}$ ), we estimated the number of starting cDNA molecules in each sample tissue solution. The gene expression rate for each member of the ET system was defined as the ratio of the number of the cDNA molecules of the ET system to the number of
GAPDH cDNA molecules multiplied by 100 . GAPDH exists in all tissues at a constant level of expression and was used as an internal control for normalizing the differences in quality and quantity of reverse-transcribed cDNAs of mRNAs extracted from each tissue (el-Husseini et al. 1994). The gene expression rate was calculated using the following formula:

[no. of molecules (ETs or ETRs)/no. of molecules $(\mathrm{GAPDH})] \times 100$.

Statistical analysis was carried out by ANOVA using Statview statistical software (Abacus Concepts, Berkeley, CA, USA). Data are presented as means \pm S.D.

\section{RESULTS}

\section{Establishment of a semi-quantitative RT-PCR analysis for the ET system: standard curve and gene expression rate}

To detect and characterize the gene expression of VIC, we established a semi-quantitative RT-PCR analysis and calculated the gene expression rate for each member of the ET system (VIC, ET-1, ET-3, ETA and ETB) as described below and in Materials and Methods. To ensure that the quantification of products is done within the linear range of the PCR amplification to avoid the plateau effect, we first determined the optimized PCR conditions (primers, number of cycles, polymerase, annealing temperature, template concentration), as shown in Table 1. Then, under the optimized conditions, we amplified the ET system and GAPDH samples along with corresponding standards at pre-determined concentrations, which we used to determine the starting concentrations of the samples, and RT-PCR products were analyzed by electrophoresis (Fig. 1). To confirm reproducibility, RT-PCR experiments were repeated three times. Figure 1, representative of the three trials, shows the expression of the ET system and GAPDH mRNA in each tissue. To confirm the specificity of amplification, the RTPCR products (Fig. 1) were analyzed by Southern blot hybridization and restriction enzyme digestion for each gene. Each specific probe was hybridized to produce bands with relative intensities parallel to those bands produced by ethidium bromide staining (Fig. 1). Southern hybridization produced only the signal bands; no accessory bands were evident (Fig. 2A). Digestion of the PCR products of each gene with restriction enzymes produced fragments of expected lengths (as in Fig. 2B), confirming the identity of the PCR products. Next, we plotted the starting number of serially diluted standard template cDNA against the relative intensity of the 


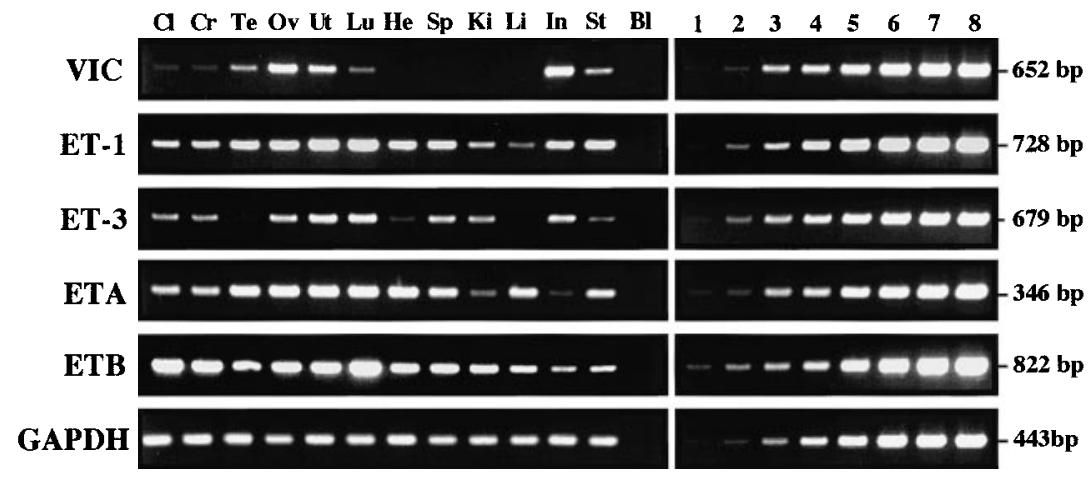

FIGURE 1. RT-PCR amplification of mRNA in tissues (Cl-St) and the standard (1-8) for semi-quantitative analysis - expression of the ET system and GAPDH genes in adult mouse tissues. Gene expression of the ET system (VIC, ET-1, ET-3, ETA and ETB) and GAPDH were examined by RT-PCR under optimized conditions (Table 1) using as templates mRNAs extracted from mouse tissues (Cl-St). Gene expression rates were estimated by comparison with amplified standard templates (1-8). Tissue samples are cerebellum $(\mathrm{Cl})$, cerebrum $(\mathrm{Cr})$, testis $(\mathrm{Te})$, ovary $(\mathrm{Ov})$, uterus $(\mathrm{Ut})$, lung $(\mathrm{Lu})$, heart $(\mathrm{He})$, spleen $(\mathrm{Sp})$, kidney $(\mathrm{Ki})$, liver $(\mathrm{Li})$, intestine $(\mathrm{In})$, and stomach $(\mathrm{St})$. In the lane used as a blank (Bl) (negative control) no template amplification was performed. Each standard template (1-8) cDNA, with a pre-determined starting concentration, was serially diluted and amplified by PCR under the same conditions (Table 1) as, and simultaneously with, the tissue samples. The relative intensity of bands (1-8) and the starting numbers of each serially diluted standard template were used to draw standard curves, as shown in Fig. 2C. The starting number of standard template per PCR reaction is described in Materials and Methods. The relative intensity of bands (Cl-St) was used to estimate the starting number of each cDNA molecule in the sample RT solution, as shown in Fig. 2C. Expression of the GAPDH gene was used as an internal normalizing control for calculating the gene expression rate (see Fig. 3).

bands (Fig. 1) and drew standard curves of relative intensity versus number of molecules, as shown in Fig. 2C. The standard curves showed linearity over two to three orders of magnitude (Fig. 2C). The relative intensities of the sample bands were also confirmed to be within the linear range of the reaction (Fig. 2C). Similarly, we were also able to confirm the identity of the PCR products and the linearity of the standard curves for ET-1, ET-3, ETA, ETB and GAPDH (T Uchide \& K Saida, unpublished data).

Using the linear range of the standard curve we estimated the number of starting molecules of template cDNAs in the reverse-transcribed sample solution, and calculated the gene expression rate by dividing the number of cDNA molecules by the number of GAPDH cDNA molecules for normalization and multiplying by 100 . Using the gene expression rate, we characterized the specificity of VIC gene expression, as shown in expression profiles of the ET system genes in Fig. 3 and Fig. 4B.

\section{Profile of VIC gene expression in adult tissues: gene expression rates of the ET system}

To gain insight into the physiological role of VIC in adult mouse tissues, we characterized the specificity of VIC gene expression by comparing gene expression rates of the ET system, normalized by GAPDH. Figure 3 shows the expression profile of the ET system genes estimated by gene expression rates. As compared with ET-1, ET-3, ETA and ETB, the expression of VIC was rather tissue-specific. A high level of VIC gene expression was observed in ovary and uterus (Fig. 3) as well as in intestine as previously described (Saida et al. 1989). Low expression was observed in stomach, lung, testis, cerebellum and cerebrum (Fig. 3) and very little cDNA was detected in heart and kidney (Fig. 2A). A high ET-1 gene expression rate, greater than one, was detected in lung, uterus, and ovary. A high level of ET-3 gene expression was detected in lung and uterus. The gene expression rate of ETB was ten 
times higher than that of ETA in cerebrum, cerebellum, and kidney. In other tissues, the ETA gene was more abundantly expressed. Except for VIC, our semi-quantitative observations essentially confirm previous observations of ET system gene expression reported in adult rat tissues (Sakurai et al. 1990, 1991, Firth \& Ratcliffe 1992, Shiba et al. 1992, de la Monte et al. 1995).

For statistical analysis of gene expression rates of the ET system in ovary, uterus and intestine, where VIC expression was observed more abundantly than in other tissues, semi-quantitative RT-PCR was independently carried out using mRNA extracted

(A)

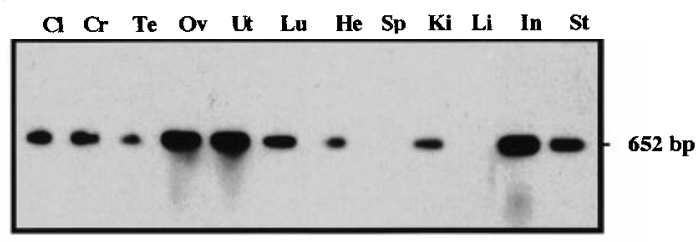

(B)

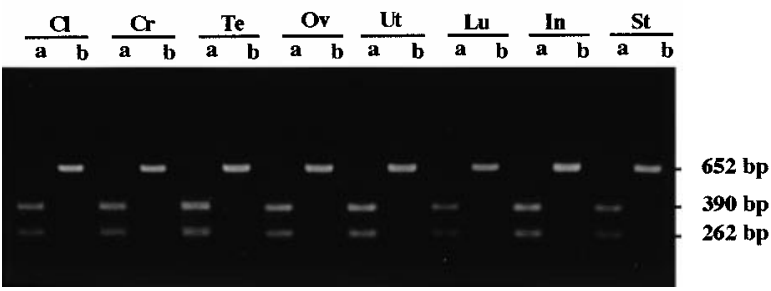

(C)

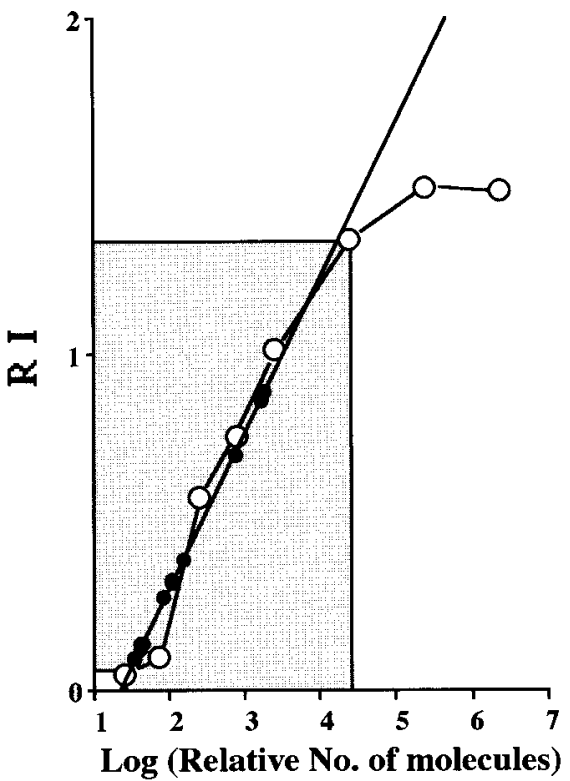

from three individual mice. The gene expression rates of VIC were $2 \cdot 0,0 \cdot 4$, and $2 \cdot 3$ in ovary, uterus and intestine respectively, as shown in Table 2 . The gene expression rates of VIC in ovary and intestine were significantly $(P<0 \cdot 01)$ higher than those of ET-1 or ET-3. The gene expression rate of VIC was 1.6 and $7 \cdot 1$ times higher than that of ET-1 in ovary and intestine respectively. In ovary, gene expression rate of ETA was significantly $(P<0 \cdot 01)$ higher than that of ETB.

\section{Profile of VIC gene expression during embryonic development: gene expression rates of the ET system}

To gain insight into the physiological role of VIC during late embryonic development, we characterized the specificity of VIC gene expression by comparing the normalized gene expression rates. The gene expression of VIC, ET-1, ET-3, ETA, $\mathrm{ETB}$, and GAPDH in whole embryos and neonates throughout prenatal development (E11, E15, E17, and $\mathrm{P} 1$ ) is shown in Fig. 4A. A diagram of the gene expression rates, showing the expression profile of the ET system, is presented in Fig. 4B. We detected VIC gene expression, along with the expression of other ET family ligand and receptor genes, during late embryonic development. VIC showed a sharp

FIGURE 2. Specificity analysis of RT-PCR products and standard curve for estimating cDNA molecules of VIC. (A) Specificity analysis by Southern blot hybridization. Electrophoresed bands of RT-PCR products of VIC shown in Fig. 1 (652 bp) were transferred onto nylon membranes and hybridized with a digoxygenin-labeled VIC probe. Relative intensities of hybridized bands, detected by chemiluminescene, correspond to intensities of bands produced by ethidium bromide staining (Fig. 1). Abbreviations of tissues as in Fig. 1. (B) Specificity analysis by restriction enzyme digestion. RT-PCR products of VIC were digested with BamHI. Digested (lane a) and undigested (lane b) samples were electrophoresed. Two fragments of predicted sizes (390 bp and $262 \mathrm{bp}$ ) were obtained, confirming the identity of the RT-PCR products (Fig. 1). (C) Linear region of the standard curve for estimating the starting number of cDNA molecules of VIC in tissues. Standard curve $(\bigcirc)$ for the quantification of VIC in tissue samples was drawn by plotting the starting number of standard template versus the relative intensity (RI) of each standard band (Fig. 1). Because the relative intensities of all bands ( ) obtained from tissue samples (Fig. 1) was confirmed to be within the linear region (shaded area) of the standard curve, the starting number of cDNA reverse-transcribed from tissue samples was estimated using the linear region. The relative intensities of bands (Fig. 1) were analyzed by computer. 

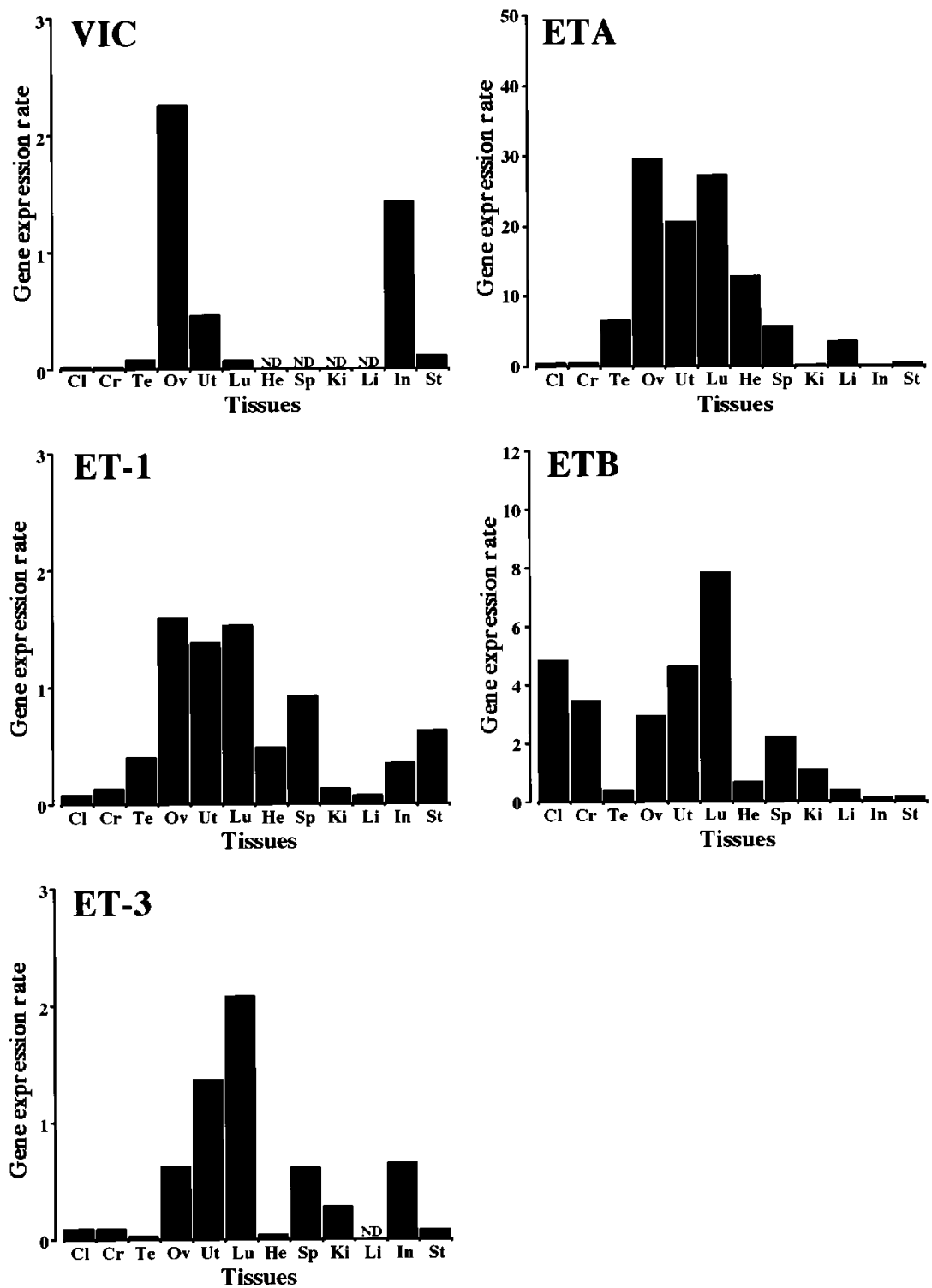

FIGURE 3. Expression profile of the ET system genes in adult mouse tissues - gene expression rates normalized by GAPDH. Gene expression rates were calculated as the ratios of the starting numbers of cDNA molecules of the ET system (VIC, ET-1, ET-3, ETA, ETB) to that of GAPDH. Abbreviations of tissues as in Fig. 1. ND, not detected.

increase between E11 and E15 and a decrease after birth similar to the changes observed in ET-1 expression. ET-3 and ETB gene expression rates showed a comparable rise and fall. Levels of ETA gene expression remained constant throughout the period examined. In contrast, the other genes showed peaked patterns. Expression of the receptor genes was found to be at higher levels than that of the ligand genes during late embryonic development. The gene expression rate of ETA was approximately ten times greater than that of ETB throughout this period, as it is in adult liver, heart, uterus, ovary, and testis (Fig. 3).

\section{DISCUSSION}

A number of reports on the distribution of gene expression of each member of the ET system in various tissues have been published (Yanagisawa 
TABLE 2. Statistical analysis of gene expression rates for the ET system. The results are the means \pm s.D. of three independent experiments

\begin{tabular}{|c|c|c|c|c|c|c|}
\hline & VIC & ET-1 & ET-3 & ETA & ETB & VIC:ET-1 \\
\hline \multicolumn{7}{|l|}{ Tissue } \\
\hline Ovary & $2 \cdot 01 \pm 0 \cdot 26 *$ & $1 \cdot 22 \pm 0 \cdot 31$ & $0 \cdot 46 \pm 0 \cdot 13$ & $24 \cdot 4 \pm 4 \cdot 66^{* *}$ & $2 \cdot 42 \pm 1 \cdot 86$ & $1 \cdot 6$ \\
\hline Uterus & $0 \cdot 36 \pm 0 \cdot 09$ & $1 \cdot 12 \pm 0 \cdot 29$ & $0.93 \pm 0 \cdot 38$ & $13 \cdot 9 \pm 7 \cdot 14$ & $2 \cdot 40 \pm 2 \cdot 15$ & $0 \cdot 3$ \\
\hline Intestine & $2 \cdot 28 \pm 0 \cdot 80^{*}$ & $0 \cdot 32 \pm 0 \cdot 02$ & $0 \cdot 60 \pm 0 \cdot 04$ & $0 \cdot 08 \pm 0 \cdot 04$ & $0 \cdot 07 \pm 0 \cdot 05$ & $7 \cdot 1$ \\
\hline
\end{tabular}

Semi-quantitative RT-PCR was independently carried out using mRNAs extracted from three individual mice $(n=3)$ for statistical analysis of the gene expression rates of the ET system in mouse ovary, uterus, and intestine.

*Gene expression rates of VIC in ovary and intestine were significantly $(P<0 \cdot 01)$ higher than those of ET-1 or ET-3. ** Gene expression rate of ETA in ovary was significantly $(P<0 \cdot 01)$ higher than that of ETB. VIC:ET-1 is the ratio of gene expression rates of VIC and ET-1.

et al. 1988, Bloch et al. 1989, MacCumber et al. 1989, Matsumoto et al. 1989, Saida et al. 1989, Arai et al. 1990, Nunez et al. 1990, Sakurai et al. 1990, 1991, Firth \& Ratcliffe 1992, Shiba et al. 1992). However, different analytical methods (Northern blot analysis, RNase protection assay, immunological detection methods, and RT-PCR), different species (rat, human, and pig), and different stages of animal development have been presented in these reports. Moreover, none of these reports has dealt with both ligands and receptors of the ET system in a single paper. Hence, it was difficult to compare gene expression quantitatively among different tissues or to compare different genes in a single tissue.

In this paper, we analyzed the distribution of the gene expression of all members in the ET system by establishing a semi-quantitative RT-PCR method. RT-PCR is useful because it is highly sensitive and therefore requires only negligible quantities of tissue, thus allowing analysis of even the smallest organs. However, we must also consider spurious or artefactual detection caused by the high sensitivity of the RT-PCR method. The confirmation of the identity of RT-PCR products is essential. Southern blot analysis and restriction enzyme digestion allow us to confirm the identity of the products (Fig. 2A and 2B). The PCR conditions including the optimization of primers (Table 1) may be useful in analyzing the expression profile of the mouse ET system in pathophysiological as well as physiological states. The semi-quantitative normalized gene expression rate allows a comparative and comprehensive analysis of gene expression, enabling us to characterize the expression profiles of a number of genes in different tissues and different developmental stages.

We previously identified the VIC gene and examined its expression in mouse tissues by Northern blot analysis (Saida et al. 1989, Saida \& Mitsui 1991). VIC gene expression was detected only in intestine and was not observed in other tissues. In this paper, we present a new insight: that the mouse VIC/ET-2 gene is expressed abundantly in ovary as well as intestine, moderately in uterus, slightly in stomach, lung, testis, cerebrum, and cerebellum, and insignificantly in kidney and heart (Figs 2A and 3 ). The observation that the ratio of VIC/ET-2 gene expression to that of ET-1 is $7 \cdot 1$ in intestine and 1.6 in ovary (Table 2 ) suggests that $\mathrm{VIC} / \mathrm{ET}-2$ may play a greater physiological role in these tissues than ET-1, if it is accepted that VIC/ET-2 and ET-1 have the same physiological activities and that peptide concentrations are parallel to mRNA concentrations. Previous reports showed that VIC/ET-2 gene expression was detected in human kidney (Bloch et al. 1991, Karet \& Davenport 1996). RNase protection assay in rat demonstrated a high level of VIC/ET-2 expression in both small and large intestine, a low level in stomach and heart, but none in lung, liver, spleen, kidney, testis and brain (Firth \& Ratcliffe 1992). de la Monte et al. (1995) investigated the expression of rat VIC/ET-2 gene using the RNase protection assay and were able to detect high levels of VIC/ET-2 mRNA in colon and relatively lower levels in small intestine and stomach. O'Reilly et al. (1993) detected the expression and alternative splicing of the ET-2 gene in human uterus. Thus, our expression profile of the VIC/ET-2 gene in mouse tissues agrees with the previous data published on rat and human. Our data adds new information, namely that the ovary and embryo also express high levels of VIC/ET-2 mRNAs, suggesting that VIC/ET-2 may have some reproductive and developmental functions and that the VIC/ ET-2 gene may also be expressed in rat and human ovary and embryo.

Cellular distribution of the VIC/ET-2 gene expression in rat gastrointestinal tract was characterized by de la Monte et al. (1995) using in situ hybridization. Specific expression signals were primarily observed in intestinal lamina propria cells, suggesting that this peptide has a role in local villous motility in intestine. However, no information on gene expression or the physiological roles 
of VIC/ET-2 in uterus and ovary has been reported. In contrast, there have been several reports on the physiological roles of ET-1 in uterus and ovary. Expression of the ET-1 gene was detected in human and porcine granulosa cells (Kubota et al. 1994, Magini et al. 1996). The peptide is considered to play an important role in granulosa cell function. Furthermore, ET-1 in rat uterus has a pivotal role

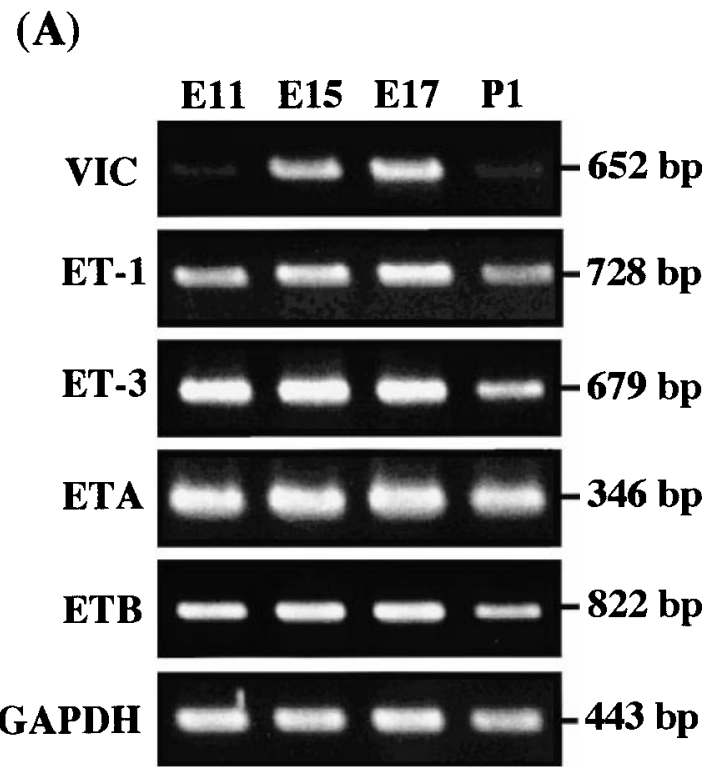

(B)

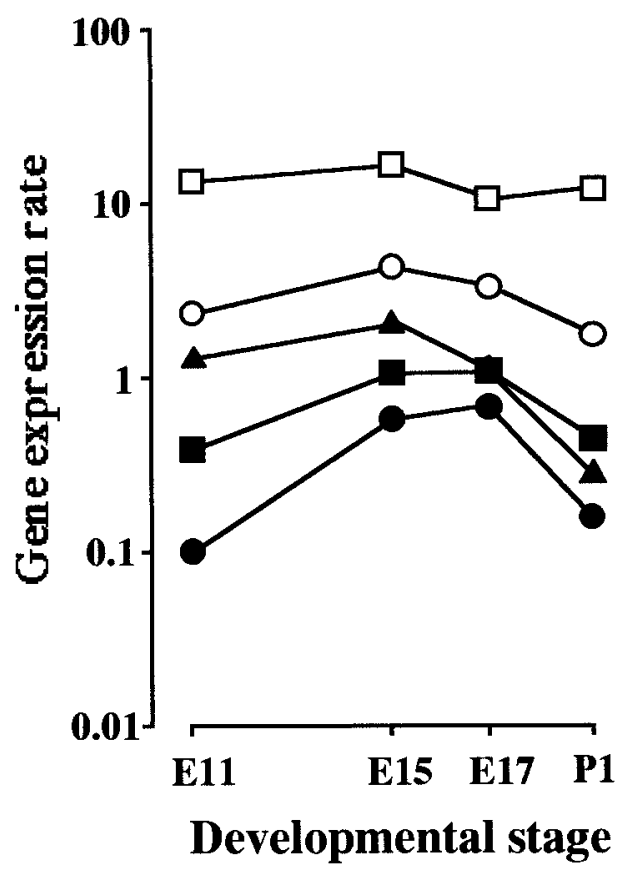

in controlling bleeding from the placental bed through myometrial contraction in the early postpartum period (Kajihara et al. 1996). Based on our knowledge of the function of ET-1, we may speculate that VIC/ET-2 could regulate physiological events in the uterus and ovary in cooperation with ET-1. Studies are currently under way in our laboratory using in situ hybridization/ histochemistry of the VIC/ET-2 gene with specific VIC/ET-2 probes that identify VIC/ET-2 expressing cells in an effort to understand this gene's physiological role in the intestine, ovary, and uterus.

The ET system plays a very important role in embryonic development. The targeted inactivation of the ET system genes demonstrates that ET-1/ ETA and ET-3/ETB are involved in neural crest-derived cell differentiation in the mouse embryo at the early stages of development. ET-3 and ETB knockout experiments demonstrate that the ET-3/ETB signaling pathway is essential for the development of enteric neurons and melanocytes (Baynash et al. 1994, Hosoda et al. 1994). Our findings (Fig. 4B) show similar expression patterns of embryonic development for ET-3 and ETB, suggesting that these genes contribute to embryonic development even in the later stages (after E11). Additionally, it has been reported that ET receptors are already widely distributed on cells not originating from neural crest cells (Brand et al. 1998). The ET system might also play an important role in the proliferation and differentiation of embryonic cells other than those derived from neural crest cells during the later stages of embryonic development after E11. An earlier report (Chan et al. 1995) demonstrated that the expression of ET-1 becomes increasingly stronger in heart, lung, eye, ear, stomach, and intestine towards the later stages of development (after E11.5). Our experiment supports this finding that ET-1 expression is high at E15 and E17. The VIC/ET-2 gene is expressed sequentially and simultaneously with ETA and ETB receptor genes in late embryonic development

FIGURE 4. Detection of VIC gene expression during late embryonic development. (A) Gene expression of the ET system and GAPDH during late embryonic development. RT-PCR was performed using mRNAs extracted from embryos 11,15 and 17 days post coitus (E11, E15, E17) and neonates 1 day post partum (P1). (B) Expression profile of the ET system gene during late embryonic development. Gene expression rates of VIC $(\bullet), \operatorname{ET}-1(\boldsymbol{\square}), \operatorname{ET}-3(\boldsymbol{\Delta}), \operatorname{ETA}(\square)$ and ETB $(\bigcirc)$ were calculated using the linear region of the standard curve (as shown in Fig. 2C) and the relative intensities of bands (Fig. 4A) as described in Materials and Methods. 
(Fig. 4B), suggesting its involvement in a variety of developmental processes in embryos. In our laboratory, in situ hybridization/histochemistry studies of the VIC/ET-2 gene using specific VIC/ET-2 probes are under way to identify the specific VIC/ET-2 expressing cells throughout embryonic development.

\section{Conclusion}

We showed the comprehensive expression profiles of ET system genes in adult mouse tissue and during late embryonic development, using gene expression rate analyzed by semi-quantitative RT-PCR. In the profiles, we identified relatively high expression of the VIC/ET-2 gene in ovary, uterus, and embryo as previously unidentified expression sites, suggesting that VIC/ET-2 may have some reproductive and developmental functions. Further investigations, including the use of gene disruption, are under way to identify the specific physiological roles of VIC/ET-2 in adult intestine, uterus, ovary, and during embryonic development.

\section{ACKNOWLEDGEMENTS}

K S gratefully acknowledges the helpful discussion and support of Drs Syuichi Oka and Noboru Tomizuka at the National Institute of Bioscience and Human-Technology (NIBH). T U and K S thank Drs Kazuo Ozawa and Toru Imamura at NIBH for helpful technical discussion and advice. We thank Drs Yasushi Makiyama, Junji Magae, Yun-Sik Lee and Yasuo Tanaka at NIBH for helpful discussion. This work was supported by a project grant to K S for Research and Development for the Elucidation of Biological Functions from the Ministry of International Trade and Industry of Japan and by a project grant of the Cooperative System for Supporting Priority Research from the Science and Technology Agency of Japan.

\section{REFERENCES}

Arai H, Hori S, Aramori I, Ohkubo H \& Nakanishi S 1990 Cloning and expression of a cDNA encoding an endothelin receptor. Nature 348 730-732.

Baynash AG, Hosoda K, Giaid A, Richardson JA, Emoto N, Hammer RE \& Yanagisawa M 1994 Interaction of endothelin-3 with endothelin-B receptor is essential for development of epidermal melanocytes and enteric neurons. Cell 79 1277-1285.

Blank MA, Fuortes M, Nyren O \& Jaffe BM 1991 Effect of endothelin-1 and vasoactive intestinal contractor on blood flow and output of vasoactive intestinal polypeptide in the feline colon. Life Science 48 1937-1944.
Bloch KD, Eddy RL, Shows TB \& Quertermous T 1989 cDNA cloning and chromosomal assignment of the gene encoding endothelin 3. Fournal of Biological Chemistry 264 18156-18161.

Bloch KD, Hong CC, Eddy RL, Shows TB \& Quertermous T 1991 cDNA cloning and chromosomal assignment of the endothelin 2 gene: vasoactive intestinal contractor peptide is rat endothelin 2. Genomics 10 236-242.

Brand M, Le Moullec J-M, Corvol P \& Gasc J-M 1998 Ontogeny of endothelins-1 and -3 , their receptors, and endothelin converting enzyme-1 in the early human embryo. Fournal of Clinical Investigation 101 549-559.

Chan TSK, Lin CXF, Chan WY, Chung SSM \& Chung SK 1995 Mouse preproendothelin-1 gene cDNA cloning, sequence analysis and determination of sites of expression during embryonic development. European Fournal of Biochemistry 234 819-826.

Clouthier DE, Hosoda K, Richardson JA, Williams SC, Yanagisawa H, Kuwaki T, Kumada M, Hammer RE \& Yanagisawa M 1998 Cranial and cardiac neural crest defects in endothelin-A receptor-deficient mice. Development 125 813-824.

Engler-Blum G, Meier M, Frank J \& Müller GA 1993 Reduction of background problems in nonradioactive Northern and Southern blot analyses enables higher sensitivity than ${ }^{32} \mathrm{P}$-based hybridization. Analytical Biochemistry 210 235-244.

Fang S, Ledlow A, Murray JA, Christensen J \& Conklin JL 1994 Vasoactive intestinal contractor: localization in the opossum esophagus and effects on motor functions. Gastroenterology 107 1621-1626.

Firth JD \& Ratcliffe PJ 1992 Organ distribution of the three rat endothelin messenger RNAs and the effects of ischemia on renal gene expression. Fournal of Clinical Investigation $\mathbf{9 0}$ $1023-1031$.

Hosoda K, Hammer RE, Richardson JA, Baynash AG, Cheung JC, Giaid A \& Yanagisawa M 1994 Targeted and natural (piebald-lethal) mutations of endothelin-B receptor gene produce megacolon associated with spotted coat color in mice. Cell 79 1267-1276.

Huggins JP, Pelton JT \& Miller RC 1993 The structure and specificity of endothelin receptors: their importance in physiology and medicine. Pharmacology and Therapeutics 59 55-123.

el-Husseini A el-D, Paterson JA \& Shiu RP 1994 Basic fibroblast growth factor (bFGF) and two of its receptors, FGFR1 and FGFR2: gene expression in the rat brain during postnatal development as determined by quantitative RT-PCR. Molecular Cell Endocrinology 104 191-200.

Inoue A, Yanagisawa M, Kimura S, Kasuya Y, Miyauchi T, Goto K \& Masaki T 1989 The human endothelin family: three structually and pharmacologically distinct isopeptides predicted by three separate genes. Proceedings of the National Academy of Sciences of the USA 86 2863-2867.

Ishida N, Tsujioka K, Tomoi M, Saida K \& Mitsui Y 1989 Differential activities of two distinct endothelin family peptides on ileum and coronary artery. FEBS Letters 247 337-340.

Kajihara T, Tomioka Y, Hata T, Ghazizadeh M \& Asano G 1996 Synthesis of endothelin-1 in rat uterus during pregnancy. Fournal of Histochemistry and Cytochemistry 44 953-957.

Kan S, Niwa M \& Taniyama K 1994 Specific receptor for vasoactive intestinal contractor in myenteric cholinergic neurones. European Fournal of Pharmacology 258 139-143.

Karet FE \& Davenport AP 1996 Localization of endothelin peptides in human kidney. Kidney International 49 382-387. 
Kubota T, Kamada S \& Aso T 1994 Endothelin-1 as a local ovarian regulator in porcine granulosa cells. Hormone Research 41 29-35.

Kurama M, Ishida N, Matsui M, Saida K \& Mitsui Y 1996 Sequence and neuronal expression of mouse endothelin-1 cDNA. Biochimica et Biophysica Acta 1307 249-253.

Kurihara Y, Kurihara H, Suzuki H, Kodama T, Maemura K, Nagai R, Oda H, Kuwaki T, Cao W-H, Kamada N, Jishage K, Ouchi Y, Azuma S, Toyoda Y, Ishikawa T, Kumada M \& Yazaki Y 1994 Elevated blood pressure and craniofacial abnormalities in mice deficient in endothelin-1. Nature 368 703-710.

Kurihara Y, Kurihara H, Oda H, Maemura K, Nagai R, Ishikawa T \& Yazaki Y 1995 Aortic arch malformations and ventricular septal defect in mice deficient in endothelin-1. Fournal of Clinical Investigation 96 293-300.

Lahav R, Ziller C, Dupin E \& Le Douarin NM 1996 Endothelin 3 promotes neural crest cell proliferation and mediates a vast increase in melanocyte number in culture. Proceedings of the National Academy of Sciences of the USA 93 3892-3897.

MacCumber MW, Ross CA, Glaser BM \& Snyder SH 1989 Endothelin: visualization of mRNAs by in situ hybridisation provides evidence for local action. Proceedings of the National Academy of Sciences of the USA 86 7285-7289.

Mckay KO, Black JL \& Armour CL 1991 The mechanism of action of endothelin in human lung. British Fournal of Pharmacology 102 422-428.

Magini A, Granchi S, Orlando C, Vannelli GB, Pellegrini S, Milani S, Grappone C, De Franco R, Susini T, Forti G \& Maggi M 1996 Expression of endothelin-1 gene and protein in human granulosa cells. Fournal of Clinical Endocrinology and Metabolism 81 1428-1433.

Matsumoto H, Suzuki N, Onda H \& Fujino M 1989 Abundance of endothelin-3 in rat intestine, pituitary gland and brain. Biochemical and Biophysical Research Communications 164 74-80.

Mazzocchi G, Rossi GP, Rebuffat P, Malendowicz LK, Markowska A \& Nussdorfer GG 1997 Endothelins stimulate deoxyribonucleic acid synthesis and cell proliferation in rat adrenal zona glomerulosa, acting through an endothelin A receptor coupled with protein kinase $\mathrm{C}$ - and tyrosine kinase-dependent signaling pathways. Endocrinology 138 2333-2337.

de la Monte SM, Quertermous T, Hong CC \& Bloch KD 1995 Regional and maturation-associated expression of endothelin 2 in rat gastrointestinal tract. Fournal of Histochemistry and Cytochemistry 43 203-209.

Nunez DJR, Brown MJ, Davenport AP, Neylon CB, Schofield JP \& Wyse RK 1990 Endothelin-1 mRNA is widely expressed in porcine and human tissues. Fournal of Clinical Investigation 85 1537-1541.
O'Reilly G, Charnock-Jones DS, Morrison JJ, Cameron IT, Davenport AP \& Smith SK 1993 Alternatively spliced mRNA for human endothelin-2 and their tissue distribution. Biochemical and Biophysical Research Communications 193 834-840.

Ozawa K, Uruno T, Miyakawa K, Seo M \& Imamura T 1996 Expression of the fibroblast growth factor family and receptor family genes during mouse brain development. Molecular Brain Research 41 279-288.

Ozawa K, Seo M \& Imamura T 1997 A quantitative method for evaluation of FGF family and FGF receptor family gene expression by RT-PCR. Brain Research Protocol 1 211-216.

Saida K \& Mitsui Y 1991 cDNA cloning, sequence analysis and tissue distribution of a precursor for vasoactive intestinal contractor (VIC). Biochimica et Biophysica Acta 1089 404-406.

Saida K, Mitsui Y \& Ishida N 1989 A novel peptide, vasoactive intestinal contractor, of a new (endothelin) peptide family. Fournal of Biological Chemistry 264 14613-14616.

Sakurai T, Yanagisawa M, Takuwa Y, Miyazaki H, Kimura S, Goto K \& Masaki T 1990 Cloning of cDNA encoding a non-isopeptide-selective subtype of the endothelin receptor. Nature 348 732-735.

Sakurai T, Yanagisawa M, Inoue A, Ryan US, Kimura S, Mitsui Y, Goto K \& Masaki T 1991 cDNA cloning, sequence analysis and tissue distribution of rat preproendothelin-1 mRNA. Biochemical and Biophysical Research Communications 175 44-47.

Shiba R, Sakurai T, Yamada G, Morimoto H, Saito A, Masaki T \& Goto K 1992 Cloning and expression of rat preproendothelin-3 cDNA. Biochemical and Biophysical Research Communications 186 588-594.

Taniyama K, Kan S, Yoshimura M \& Niwa M 1993 Involvement of cholinergic neurons in intestinal contraction caused by vasoactive intestinal contractor. European fournal of Pharmacology 235 149-151.

Wollberg Z, Bdolah A, Galron R, Sokolovsky M \& Kochva E 1991 Contractile effects and binding properties of endothelins/sarafotoxins in the guinea pig ileum. European Fournal of Pharmacology 198 31-36.

Yanagisawa M, Kurihara H, Kimura S, Tomobe Y, Kobayashi M, Mitsui Y, Yazaki Y, Goto K \& Masaki T 1988 A novel potent vasoconstrictor peptide produced by vascular endothelial cells. Nature 332 411-415.

Yoshinaga M, Chijiiwa Y, Misawa T, Harada N \& Nawata H 1992 Endothelin B receptor on guinea pig small intestinal smooth muscle cells. American Fournal of Physiology 262 G308-G311.

REVISED MANUSCRIPT RECEIVED 26 October 1998 